\title{
At Site Flood Frequency Analysis of Baitarani River at Champua Watershed, Odisha Rebati Sinam ${ }^{* 1}$,
}

${ }^{* 1}$ Research Scholar, Centre for the Study of Regional Development, Jawaharlal Nehru University, New Delhi, India Email address : rebati31_ssf@jnu.ac.in

\begin{abstract}
For any development of hydraulic structures and dam modelling, flood frequency analysis is an effective tool to determine the appropriate measures and strategy. Flood frequency analysis has been conventionally used in hydraulic engineering and floodplain management. The present study is an attempt to estimate the expected flood using two probability distributions: Gumbel distribution and Log Pearson III distribution at Champua watershed, Upper Baitarani River Basin, Odisha. The analysis is based on annual maximum flood time series from 1991 to 2018 (28 years) obtained from Water Resources Information System at the Champua gauging station. Three Goodness of fit methods namely Kolmogorov Smirnov, Anderson Darling and Chi Squared tests are used to choose the better model. From the analysis, expected flood for return period 2, 10, 25, 50, 100 and 1000 years are calculated. Gumbel give an expected flood 521.72 cumecs while Log Pearson III give an expected flood of 493.17 cumecs for 2 years return period. It is observed that Gumbel estimated a higher values for all the said return period except for 1000 years where Log Pearson III predicted a much higher values. Goodness of test show inconsistent results. While Chi-squared test indicate Gumbel Method as the better model, the other two tests show that Log Pearson III is the better fitting model for the given dataset. Therefore, Log Pearson III is chosen as the best model. However, the results from both the distributions can be referred for storm management.
\end{abstract}

Keywords: Gumbel distribution, Log Pearson III, Baitarani River, Flood Frequency Analysis, Goodness of Fit.

\section{INTRODUCTION}

Flood is 'unusually a high stage of a river owing to heavy discharge from rainfall or melting of snow/ice or both in quantities too great to be content in the normal water surface elevations of the river channels as a result of the meteorological combination' (Raghunath, 1985). Flood can be quite destructive and risky leading to loss of lives and properties costing crores of rupees. In India, more than thousands of crores of rupees are spent annually for flood control measures and forecasting. The hydrograph of extreme floods can give a lot of valuable data for the purpose of hydrologic design. At a given station, flood peak tends to vary from year to year and their magnitude constitute a hydrologic series which enable one to assign a frequency to a given flood peak value (Subramanya, 2013). The frequency of peak discharge is important in the design of spillways, dams and barrages, capacities of bridge and culvert waterways (Yue, 1999; Bhagat, 2017; Mujere, 2011; Mukherjee, 2013; Bhuyan et al., 2010; Strupczewski et al., 2014; Hire et al., 2018) and flood plain management (Mujere, 2011; Parhi, 2018). A design flood is the flood adopted for designing any hydraulic structures like spillways, flood banks, etc. of any desired 
recurrence interval depending upon the degree of protection to be offered and cost economics of structures to the desired flood stage (Raghunath, 1985). Flood frequency analysis is the estimation of flood events to determine how often it will occur. This technique is used mostly by engineers and hydrologists which basically consists of estimating flood peak values for a set of non-exceedance (Bhagat, 2017; Bhat et al., 2019; Kumar et al., 2003; Abdo et al., 2006). It involves fitting of probability model to a set of annual flood peaks for a catchment from which future prediction of extreme events can be determined. Flood frequency analysis can be done using two kinds of discharge data: Annual Maximum flood series and Partial duration series (Subramanya, 2013). After the procurement of the required data, the conventional procedure for the analysis involve determining the right probability distribution for modelling the data, parameter estimations of the distribution and calculating the goodness of fit of the said model. Accordingly, the desired model can be used for estimating future extreme events after validation for a desired return period. There are multiple numbers of probability distributions used for flood frequency analysis. Some noteworthy one includes generalized extreme value distribution, normal, log normal, log pearson III, log-logistic, exponential, generalised pareto, gamma, Weibull, Gumbel, etc. among others (Farooq et al., 2018; Karim et al., 1995; Fiorentino et al., 1985; Cassalho et al., 2018).

For parameter estimation, popular methods includes maximum likelihood method, methods of moments, moment ratios, L-moment, Bayesian paradigm, etc.(Saf, 2009; Lee et al., 2019; Hussain et al., 2009; Parida et al., 1998; Noto et al., 2009; Bhuyan et al., 2010; Vivekanandan, 2015a; Kumar et al., 2003; Drissia et al., 2019; Kumar et al., 2015) Most commonly used Goodness of fit methods includes that of Kolmogorov-Smirnov test, Anderson Darling test,
Chi-Squared test apart from normal regression coefficient and root mean square estimates (Nahdiya et al., 2012; Nabi et al., 2013; Al-Subh, 2014; Farooq et al., 2018; Vivekanandan, 2015b). Flood frequency analysis can be divided into two kinds: At Site and Regional Frequency analysis (Ellouze et al, 2008; Drissia et al., 2019). Regional Frequency analysis is the evolving frequency techniques applied specially for ungauged stations for a homogenous regions where it incorporates the regional basin characteristics of the hydrological unit (Saf, 2009; Ellouze et al., 2008; Lee et al., 2019; Parida et al., 1998; Bhuyan et al., 2010). The techniques and modelling of flood frequency have improved tremendously over the years as new methods and better simulation technology evolved. Of recent, new studies on frequency analysis using soft computing techniques like Fuzzy Clustering Algorithm, Artificial Neural Network and Artificial Intelligence system has enter the realm of hydrological studies (Danish et al., 2017; Kumar et al., 2015).

Hydraulic engineers and Hydrologists have published multiple number of papers on flood frequency which involves estimation of frequency variates, comparison of the probability distribution, parameter estimation and determination of best fit models. Abdo et al. (2006) have conducted at site and regional flood frequency analysis using extreme value distributions in Blue Nile basin and Atbara River. Drissia et al. (2019) have also analysed the difference between at site and regional flood frequency using L-moments and L-moment ratio in 43 discharge gauging stations in the state of Kerala. They incorporated five distributions namely Generalised Extreme Value, Generalised Logistic, Generalised Pareto, Generalised Normal and Log Pearson III. Rahman et al. (2014) evaluated regional flood frequency analysis in Northern and Razavi Khorasan provinces using Log Pearson III distribution. Regional flood analysis on Pannonian Basin has been done by Leščešen et al. 
(2019) using L-moments and annual maximum series methods. Annual Maximum methods was used by Hire et al. (2018) for frequency analysis of Par River at Nanivahial site. Mukherjee (2013) has estimated the flood peak of Subarnekha River using Gumbel distribution. Ganamala et al. (2017) calculated expected flood at Vijayawada using Gumbel's, California's and Hazen's methods. Study on Jhelum river was conducted by Bhat et al. (2019). New techniques like Bivariate flood frequency analysis using copula are done by Stamatatou et al. (2018) and soft computing techniques are executed by Danish et al. (2017) and Kumar et al. (2015)

However, Flood estimation techniques using these methods are not free from errors and problems. Problem arising due to short time series, corrupted data, oversimplified assumptions, wrongly selected of fitting model or probability distributions can lead to uncertainty and inaccuracy in the results (Strupczewski et al., 2014). This can affect in the real formulation of the design flood. Consequently affecting the design of the hydraulic structures. Therefore, it is imperative to apply every possible and viable models to the given sample data and determine the right distribution and obtain the results with minimum errors.

In this paper, at site flood frequency analysis is conducted at Champua watershed of Baitarani River using two probability distributions: Gumbel and Log Pearson III distributions. The expected floods obtained by these methods are compared and analysed. Goodness of fit is examined using three methods: Kolmogorov-Smirnov, Anderson-Darling and Chi-squared test.

\section{METHODS AND MATERIAL}

\section{A. Study Area}

Baitarani River rises from the Guptaganga hills in Gonasika village of Keonjhar (or Kendujhar) district in Baitarani River rises from the Guptaganga hills in Gonasika village of Keonjhar (or Kendujhar) district in Odisha at an elevation of $910 \mathrm{~m}$ and flow through a distance of 365 kilometres before draining out to Bay of Bengal. From the point of origin, the river flows toward northern direction for a distance of about 80 kilometres and it takes a sudden 90 degree turn to its right at Champua.

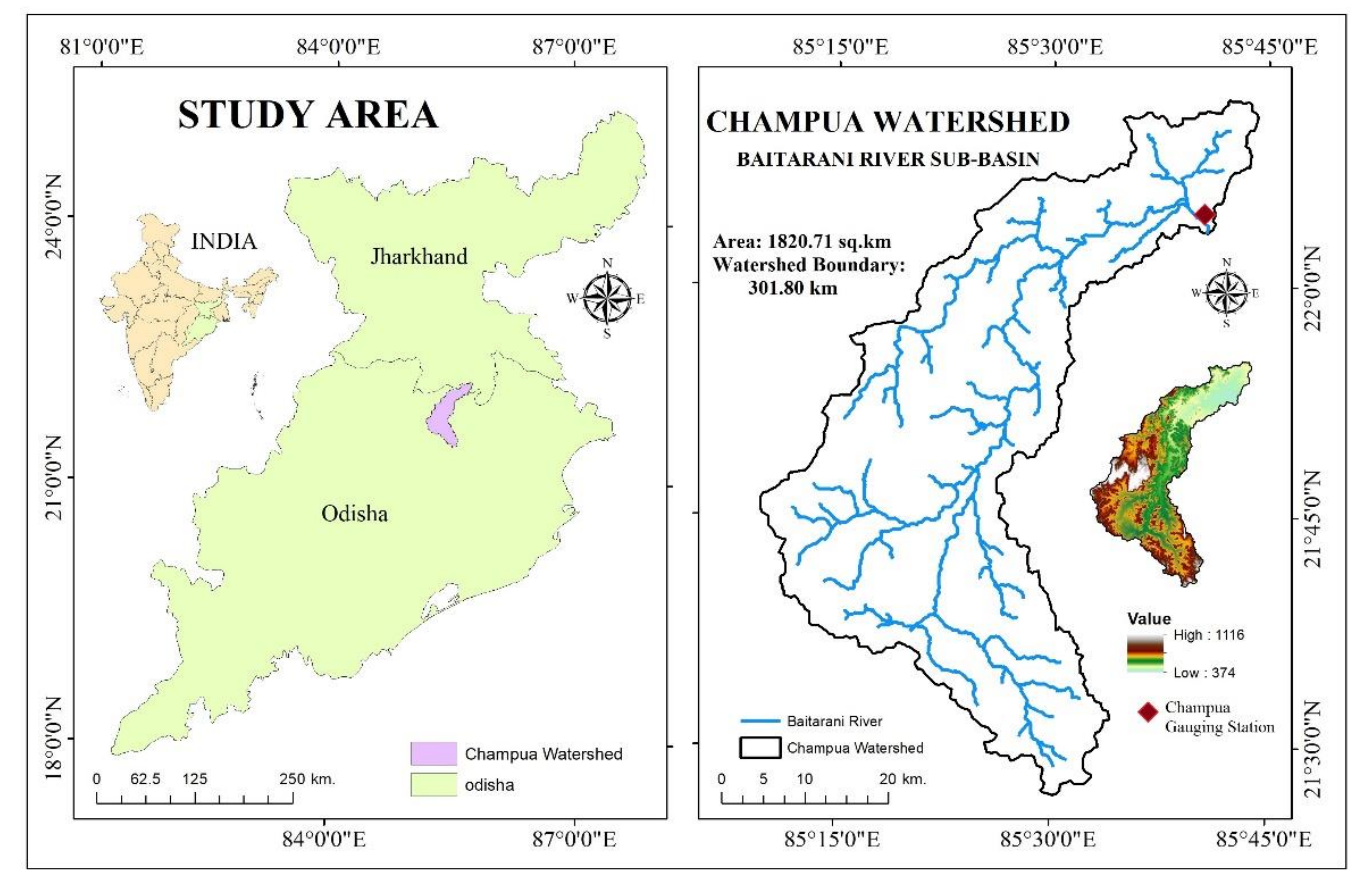


Fig. 1: Study Area

From here, it flows southward which is joined by various tributaries from its left and right side. It joined Brahmani River at Dharma near Chandabali after entering the floodplains at Anandapur (or Anandpur), meeting the deltaic zone at Akhuapada where it branches off into different distributaries before draining into the Bay of Bengal.

\section{B. Database and Methodology}

There are only few gauging stations where continuous data is available. At present only one station (Champua) has continuous discharge data from 1991 onwards. Discharge data recorded at Champua station

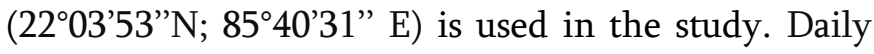
discharge data from 1991-2018 (28 years) is obtained from India-WRIS online website and the maximum one day flood peaks for all the year is generated.

(http://indiawris.gov.in/wris/\#/waterData/)

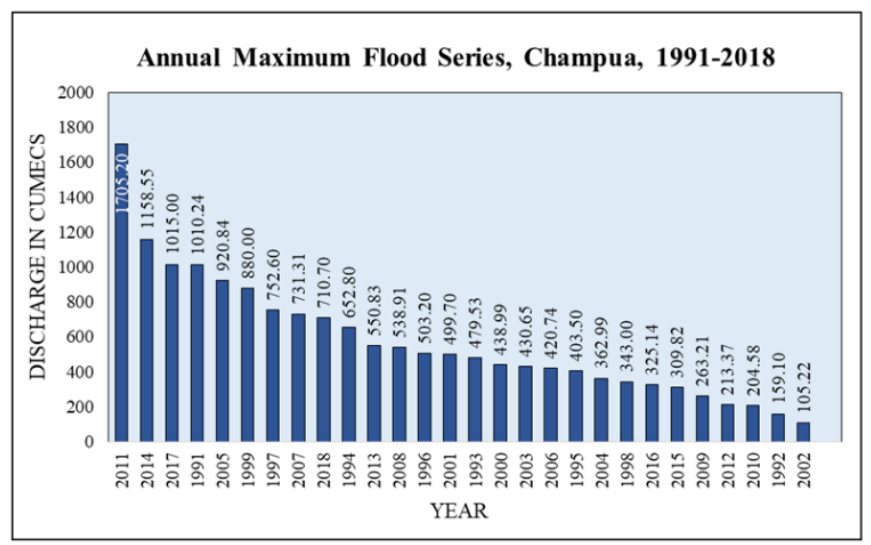

Fig. 2: Annual Maximum Flood Series, Champua

The flood frequency analysis of the Sub-Basin is done using two probability distribution functions:

1. Gumbel Maximum Distribution

2. Log Pearson III Distribution

\section{1) Gumbel Distribution}

Chow (1951) has shown that most frequency distribution functions applicable in hydrologic studies can be expressed in the form of

$$
\mathrm{X}_{\mathrm{t}}=\mathrm{X}_{\mathrm{m}}+\mathrm{KS} S_{\mathrm{x}}
$$

Also called the General equation of hydrologic analysis.

Where, $\mathrm{X}_{\mathrm{t}}=$ Value of the variate $\mathrm{X}$ of a random hydrologic series with a return period $\mathrm{T}, \mathrm{X}_{\mathrm{m}}=$ Mean of the variate, $S_{x}=$ Standard deviation of the variate, $K=$ Frequency factor which depends upon the return period, $\mathrm{T}$ and the assumed frequency distribution.

Gumbel distribution is most commonly used for analysing flood data and was introduced by E. J. Gumbel $(1941,1958)$. It is one of the most widely used for extreme values in hydrological and meteorological studies for prediction of flood peaks, maximum rainfall, maximum wind speed, etc. (Onen et al., 2017; Nahdiya et al., 2012; Jeong et al., 2014; Loaiciga et al., 1999; Farooq et al., 2018; Mujere, 2011; Bhagat, 2017; Yue et al., 1999; Yue, 2000; Mukherjee, 2013; Bhat et al., 2019)

According to Gumbel, a flood is the largest of the 365 daily flows and the annual flood series constitute a series of largest values of flows. Here, analysis is done for the maximum values of flood so it is also called as Gumbel Max distribution. As per the Gumbel theory of extreme values, the value of the variate $X$ with return period $\mathrm{T}$ is given by the equation,

$$
X_{T}=\bar{X}+K \sigma_{n-1}
$$

Where, $\sigma_{n-1}=$ Standard deviation of the sample which is given by $\sqrt{\frac{\sum(X-\bar{X})^{2}}{N-1}}$ where $\mathrm{N}$ is sample size; $K$ (Frequency Factor) $=\frac{y_{T-\bar{y}_{n}}}{s_{n}}$, where $y_{T}=$ reduced variate, a function of return period $\mathrm{T}$ and expressed as $y_{T}=-\left[\ln \cdot \ln \frac{T}{T-1}\right]$ or $y_{T}=\left[0.834+2.303 \log \log \frac{T}{T-1}\right]$; $\bar{y}_{n}=$ reduced mean and $S_{n}=$ reduced standard deviation. They are determined from Gumbel table for $N \rightarrow \infty, y_{n} \rightarrow 0.577$ and $N \rightarrow \infty, S_{n} \rightarrow 1.2825$ 


\section{2) Log Pearson III distribution}

This is one of the probability distributions developed by Karl Pearson. It was popularised by US Water Resources Council as it was extensively used for its hydrologic analysis (Farooq et al., 2018; McMahon et al., 1981; Drissia et al., 2019; Yadav et al., 1998; Bhat et al., 2019)

In this distribution, the variates are converted into logarithmic form and the transformed variates are analysed. If $X$ represents the variate of the sample, then the transformed variate is represented by $\mathrm{Z}$ expressed as

$$
Z=\log X
$$

For this $\mathrm{Z}$ series, the expected variate for any return period is given by

$$
Z_{T}=\bar{Z}+K_{Z} \sigma_{Z}
$$

Where, $K_{Z}=$ frequency factor which is a function of $\mathrm{T}$ and $C_{s}$ (Coefficient of Skew of Z)

$\sigma_{Z}=$ standard deviation of the $\mathrm{Z}$ variate series $=$

$\sqrt{\sum(Z-\bar{Z})^{2} /(N-1)}$

$C_{s}=\frac{N \sum(Z-\bar{Z})^{3}}{(N-1)(N-2)\left(\sigma_{Z}\right)^{3}}$

$\bar{Z}=$ mean of the $\mathrm{Z}$ values

$\mathrm{N}$ = sample size

After finding $Z_{T}$, the value of $\mathrm{X}_{\mathrm{T}}$ is given by:

$$
\mathrm{X}_{\mathrm{T}}=\operatorname{antilog}\left(Z_{T}\right)
$$

\section{3) Goodness of Fit}

Goodness of fit test determine whether a particular probability distribution fit the observed data. This is a statistical algorithm that can be used to check the distance between the observed data and expected data. Goodness of fit test has been used for flood frequency analysis to compare different probability distributions and stem out the best model for the given dataset or basin. For the present study, three goodness of test methods: Kolmogorov Smirnov, Anderson Darling, Chi-Squared tests have been applied to compare the two models and based on their cumulative result, choose the best model for the study area.

The analysis of the test is done using a software called EasyFit 5.6 Professional developed by MathWave Technologies.

(http://www.mathwave.com/)

\section{RESULTS AND DISCUSSION}

The highest ever recorded flood during 1991-2018 was 1705.20 cumecs in 2011 and the lowest flood was 105.22 cumecs in 2002. The mean annual maximum flood is 574.63 cumecs with a standard deviation of 354.79 cumecs and a coefficient of variation of $62 \%$.

\section{A. Weibull's Formula}

The plotting position formula developed by Weibull is used to analyse the probability of occurrence and calculate return period of the observed data. This is to understand the pattern of discharge over the years. The annual flood peak of 1705.20 has a return period of 29 years with a probability of occurrence of $3.4 \%$. The second annual maximum flood of 1158.55 cumecs has a return period of 14.5 years with a probability of occurrence of $6.9 \%$. While a flood of 105.22 cumecs has return period of one year with $96 \%$ probability of occurrence. The Year 2011 shows unusually high flood as compared to the other years.

\begin{tabular}{|c|c|c|c|c|}
\hline Year & $\mathrm{X}$ & Rank $(\mathrm{m})$ & $\mathrm{P}$ & $\mathrm{T}$ \\
\hline 2011 & 1705.20 & 1 & 0.034 & 29.00 \\
\hline 2014 & 1158.55 & 2 & 0.069 & 14.50 \\
\hline 2017 & 1015.00 & 3 & 0.103 & 9.67 \\
\hline 1991 & 1010.24 & 4 & 0.138 & 7.25 \\
\hline 2005 & 920.84 & 5 & 0.172 & 5.80 \\
\hline 1999 & 880.00 & 6 & 0.207 & 4.83 \\
\hline 1997 & 752.60 & 7 & 0.241 & 4.14 \\
\hline 2007 & 731.31 & 8 & 0.276 & 3.63 \\
\hline 2018 & 710.70 & 9 & 0.310 & 3.22 \\
\hline 1994 & 652.80 & 10 & 0.345 & 2.90 \\
\hline 2013 & 550.83 & 11 & 0.379 & 2.64 \\
\hline 2008 & 538.91 & 12 & 0.414 & 2.42 \\
\hline
\end{tabular}




\begin{tabular}{|c|c|c|c|c|c|}
\hline 1996 & \multicolumn{2}{|c|}{503.20} & 13 & 0.448 & 2.23 \\
\hline 2001 & \multicolumn{2}{|c|}{499.70} & 14 & 0.483 & 2.07 \\
\hline 1993 & \multicolumn{2}{|c|}{479.53} & 15 & 0.517 & 1.93 \\
\hline 2000 & \multicolumn{2}{|c|}{438.99} & 16 & 0.552 & 1.81 \\
\hline 2003 & \multicolumn{2}{|c|}{430.65} & 17 & 0.586 & 1.71 \\
\hline 2006 & \multicolumn{2}{|c|}{420.74} & 18 & 0.621 & 1.61 \\
\hline 1995 & \multicolumn{2}{|c|}{403.50} & 19 & 0.655 & 1.53 \\
\hline 2004 & \multicolumn{2}{|c|}{362.99} & 20 & 0.690 & 1.45 \\
\hline 1998 & \multicolumn{2}{|c|}{343.00} & 21 & 0.724 & 1.38 \\
\hline 2016 & \multicolumn{2}{|c|}{325.14} & 22 & 0.759 & 1.32 \\
\hline 2015 & \multicolumn{2}{|c|}{309.82} & 23 & 0.793 & 1.26 \\
\hline 2009 & \multicolumn{2}{|c|}{263.21} & 24 & 0.828 & 1.21 \\
\hline 2012 & \multicolumn{2}{|c|}{213.37} & 25 & 0.862 & 1.16 \\
\hline 2010 & \multicolumn{2}{|c|}{204.58} & 26 & 0.897 & 1.12 \\
\hline 1992 & \multicolumn{2}{|c|}{159.10} & 27 & 0.931 & 1.07 \\
\hline 2002 & \multicolumn{2}{|c|}{105.22} & 28 & 0.966 & 1.04 \\
\hline \multicolumn{6}{|c|}{$\begin{array}{c}\mathrm{X}=\text { Annual Maximum Flood; } \mathrm{P}=\text { Probability of } \\
\text { Occurrence; } \mathrm{T}=\text { Return Period }\end{array}$} \\
\hline \multicolumn{6}{|c|}{$\begin{array}{l}\text { Table 1: Calculation of Recurrence interval and } \\
\text { probability of occurrence using Weibull's formula }\end{array}$} \\
\hline \multicolumn{2}{|c|}{ Statistic } & Value & \multicolumn{2}{|c|}{ Percentile } & Value \\
\hline \multicolumn{2}{|c|}{ Sample Size } & 28 & \multicolumn{2}{|c|}{ Min } & 105.2 \\
\hline \multicolumn{2}{|c|}{ Range } & 1600 & \multicolumn{2}{|c|}{$5 \%$} & 129.5 \\
\hline \multicolumn{2}{|c|}{ Mean } & 574.63 & \multicolumn{2}{|c|}{$10 \%$} & 200.0 \\
\hline \multicolumn{2}{|c|}{ Variance } & 125880 & & (Q1) & 329.6 \\
\hline Std. De & & 354.79 & $50 \%$ & Median) & 489.6 \\
\hline Coef. of & & 0.62 & & (Q3) & 747.3 \\
\hline Std. F & & 67.05 & & $\%$ & 1029.4 \\
\hline Skew & & 1.36 & & $\%$ & 1459.2 \\
\hline Excess $\mathrm{K}$ & & 2.44 & & Иax & 1705.2 \\
\hline
\end{tabular}

Table 2: Descriptive statistics

Figure no. 3 shows the Flood Frequency Plot of annual maximum flood peak and return period. The goodness of fit line show a $\mathrm{R}^{2}$ of 0.9785 which is fairly a good presentation of the distribution. The equation of $\mathrm{X}=415.59 \mathrm{ln}(\mathrm{T})+182.87$ denotes the relationship between the discharge and return period.

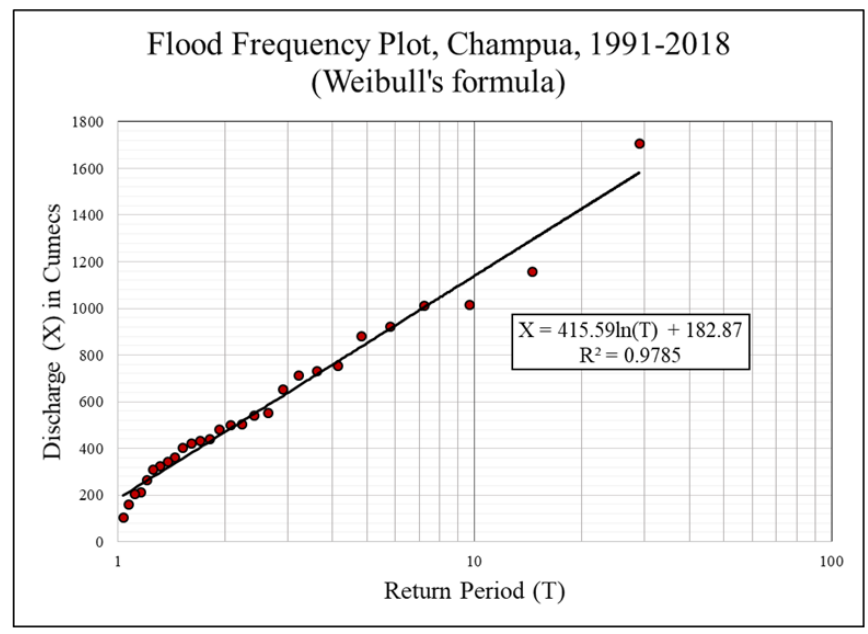

Fig. 3: Flood Frequency Plot at Champua using Weibull's formula

\begin{tabular}{|c|c|c|c|}
\hline $\mathrm{T}$ & Yt & $\mathrm{K}$ & $\begin{array}{c}\text { Expected flood } \\
\left(\mathrm{X}_{\mathrm{T}}\right)\end{array}$ \\
\hline 2 & 0.37 & -0.15 & 521.72 \\
\hline 10 & 2.25 & 1.55 & 1115.85 \\
\hline 25 & 3.20 & 2.41 & 1414.88 \\
\hline 50 & 3.90 & 3.05 & 1636.72 \\
\hline 100 & 4.60 & 3.68 & 1856.93 \\
\hline 200 & 5.30 & 4.31 & 2076.33 \\
\hline 1000 & 6.91 & 5.77 & 2584.54 \\
\hline \multicolumn{3}{|c|}{$\mathrm{T}=$ Return Period; Y $\mathrm{Y}_{\mathrm{t}}=$ Reduced Variate; $\mathrm{K}=$} \\
\hline \multicolumn{4}{|c|}{ Frequency Factor } \\
\hline
\end{tabular}

Table 3: Calculation of Expected flood using Gumbel distribution

\begin{tabular}{|c|c|c|c|c|}
\hline \multirow[t]{2}{*}{$\mathrm{T}$} & $\mathrm{Z}=2.680$ & $\sigma=0.2749$ & $C_{s}=-0.32$ & \multirow[t]{2}{*}{$\mathrm{X}_{\mathrm{T}}$} \\
\hline & $\begin{array}{c}\mathrm{K}_{\mathrm{z}} \text { for } \mathrm{C}_{\mathrm{z}}= \\
-0.32\end{array}$ & $\mathrm{~K}_{z} \sigma$ & $\mathrm{Z}_{\mathrm{T}}$ & \\
\hline 2 & 0.05 & 0.01 & 2.69 & 493.17 \\
\hline 10 & 1.245 & 0.34 & 3.02 & 1052.57 \\
\hline 25 & 1.643 & 0.45 & 3.13 & 1354.13 \\
\hline 50 & 1.89 & 0.52 & 3.20 & 1583.29 \\
\hline 100 & 2.104 & 0.58 & 3.26 & 1812.97 \\
\hline 200 & 2.294 & 0.63 & 3.31 & 2044.66 \\
\hline 1000 & 2.675 & 0.74 & 3.42 & 2602.30 \\
\hline
\end{tabular}

$\mathrm{T}=$ Return Period; $\sigma=$ Standard Deviation; $\mathrm{C}_{\mathrm{s}}=$

Coefficient of Skewness; $\mathrm{K}_{\mathrm{z}}=$ Frequency Factor

Table 4: Calculation of Expected flood using Log Pearson III distribution 


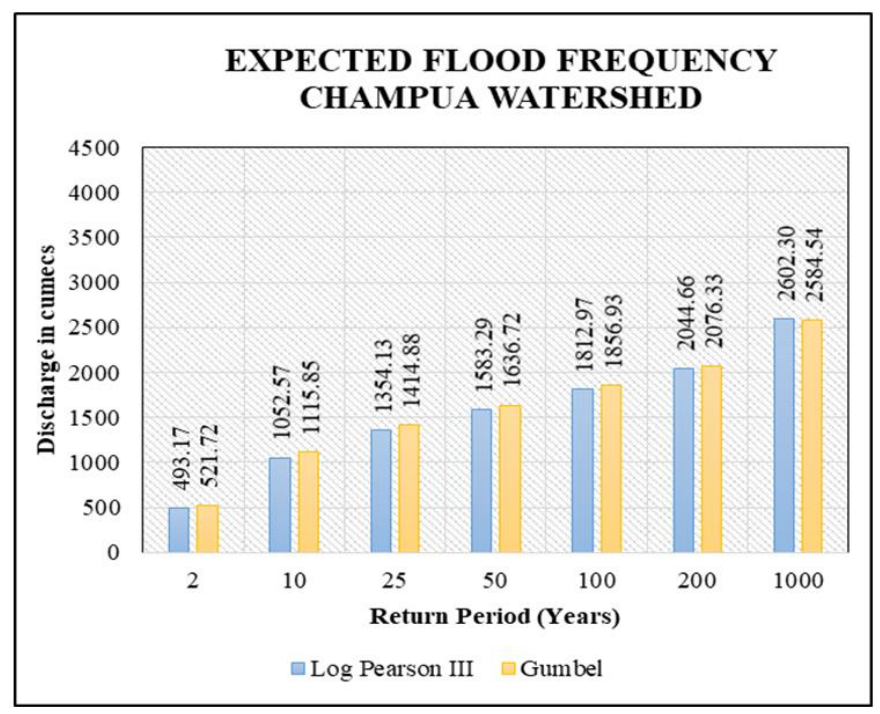

Fig. 4: Comparison of Expected Flood Estimates by

Gumbel and Log Pearson III distribution

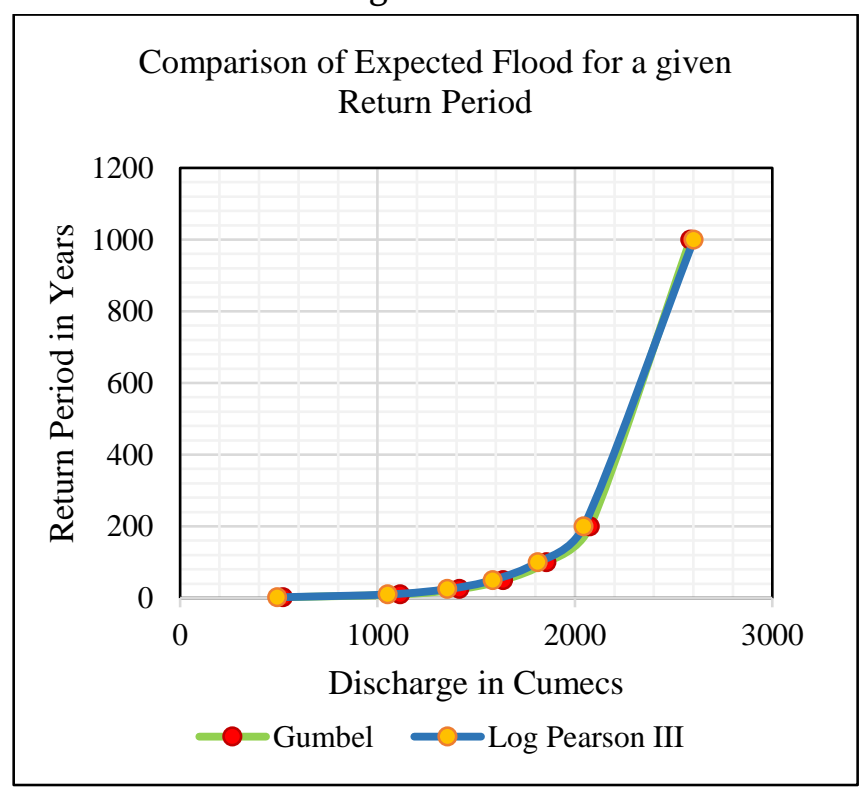

Fig. 5: Plot of expected flood obtained by Gumbel and Log Pearson III distribution

\begin{tabular}{|c|l|l|l|l|}
\hline \multirow{2}{*}{$\begin{array}{l}\text { GOF } \\
\text { method }\end{array}$} & \multicolumn{2}{|l|}{ Gumbel Max } & \multicolumn{2}{l|}{ Log Pearson III } \\
\cline { 2 - 5 } & Statistics & Rank & Statistics & Rank \\
\hline $\begin{array}{c}\text { Kolmogorov } \\
\text { Smirnov }\end{array}$ & 0.101 & 2 & 0.077 & 1 \\
\hline $\begin{array}{c}\text { Anderson } \\
\text { Darling }\end{array}$ & 0.197 & 2 & 0.118 & 1 \\
\hline $\begin{array}{c}\text { Chi- } \\
\text { Squared }\end{array}$ & 0.689 & 1 & 0.762 & 2 \\
\hline
\end{tabular}

Table 5: Goodness of Fit test

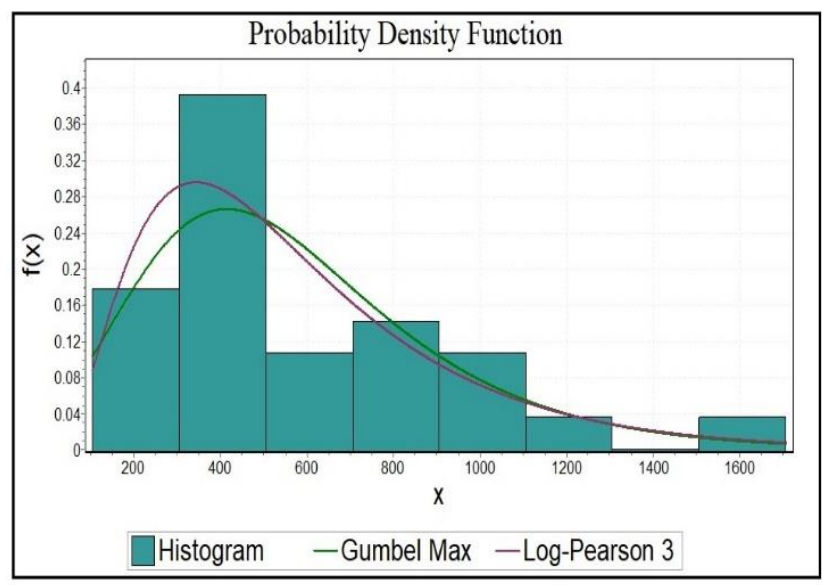

Fig. 6: Probability Density Function of Gumbel and Log pearson III

Baitarani river sub-basin falls in sub-tropical monsoon climatic zone which received an annual monsoon rainfall of 1200 to $1500 \mathrm{~mm}$. More than $80 \%$ of the total annual rainfall is concentrated during four monsoon months (June to September). The upper catchment of the river is primarily a hilly region and due to large number of drainage network, it permit the runoff to gush into the main channel with greater force within a short period of time. Moreover, due to heaving mining operations and Jhum cultivation in the catchment area, large quantity of sediments are added to the river especially during the monsoon. This consequently lower the carrying capacity of the river leading to high flood even with medium rainfall. Flooding becomes an annual events in the basin. Therefore, it is imperative that one understand the hydro meteorological dynamics of the basin so as to content the flood and develop effective preparedness measures.

The flood frequency analysis of Champua watershed in the upper catchment is being conducted using Gumbel, Log Pearson III distributions. The estimation of the expected flood for return period 2, 10, 25, 50, 100, 200 and 1000 years are tabulated in table no. 3 and 4 . The observed mean values of the discharge is 574.63 cumecs with a standard deviation of 354.79 cumecs and a coefficient of variation of $61.74 \%$ which 
is fairly a high variation. For return period of 2 years, Gumbel give an expected flood 521.72 cumecs whereas Log Pearson III gives 493.17 cumecs. One interesting result is that for 25, 50, 100, 200 return period, Gumbel predicted a higher flood estimates but for 1000 years, it estimated a lower variate than that of Log Pearson III (Figure no. 4 and 5).

The suitability of the models are being tested using three goodness of fit methods (Table no. 5). The test result show different result. While Chi-squared test favours Gumbel as the better fitting model, Kolmogorov Smirnov and Anderson darling test favours Log Pearson III as the most suitable model. The visual validation of the better fitting model is presented in the formed of probability density function in figure no. 6 which visually indicates that Log Pearson III shows relatively better fit for the present study. Hence, Log Pearson III distribution can be taken as the suitable model for Champua watershed.

Nevertheless, it is to be noted that flood frequency analysis are marred with technical errors and problems of under or over estimation. The inconsistencies in the data records and short data series may not present the best results leading to uncertainties. The estimation of flood for period higher than 100 years based on 28 years dataset can be misleading. This is the limitation of the present study. Testing of other probability distributions are further suggested to find out the best model for the given region.

\section{IV.CONCLUSION}

A comparative analysis of flood frequency estimates has been performed for Champua gauging station using two conventional probability distributions: Gumbel and Log Pearson III for a data record of 28 years. Both the methods show similar expected flood with Gumbel showing a higher estimates except for return period 1000 years. The suitability of the model is being tested using Kolmogorov-Smirnov test, Anderson Darling test and Chi-squared test. While Chi-squared test favours Gumbel as the better model, the other two methods shows that Log Pearson III is the better model. Despite the inconsistency in the test result, both the result can be considered in complementary for developing design flood and storm management.

\section{ACKNOWLEDGEMENT}

I want to extend my gratitude to Prof. Milap Chand Sharma and Prof. Omvir Singh for valuable feedback and encouragement. Much thanks are due to anonymous reviewers for their inputs and suggestions.

\section{REFERENCES}

[1]. Abdo, G., Sonbol, M., \& Willems, P. (2006). Flood frequency analysis of the Eastern Nile Rivers. Friend/Nile, 13621(April), 1-13. Retrieved from http://www.unesco.org/fileadmin/MULTIMEDI A/FIELD/Cairo/pdf/REGIONAL_FLOOD_FREQ UENCY_ANALYSIS.pdf

[2]. Al-Subh, S. A. (2014). Goodness of fit test for gumbel distribution based on Kullback-Leibler information using several different estimators. Applied Mathematical Sciences, 8(93-96), 47034712. https://doi.org/10.12988/ams.2014.46470

[3]. Bhagat, N. (2017). Flood frequency analysis using Gumbel Distribution Method: A case study of Lower Mahi Basin, India. Journal of Water Resources and Ocean Science, 6(4), 51. https://doi.org/10.11648/j.wros.20170604.11

[4]. Bhat, M. S., Alam, A., Ahmad, B., Kotlia, B. S., Farooq, H., Taloor, A. K., \& Ahmad, S. (2019). Flood frequency analysis of river Jhelum in Kashmir basin. Quaternary International, 
507(September),

288-294.

https://doi.org/10.1016/j.quaint.2018.09.039

[5]. Bhuyan, A., Borah, M., \& Kumar, R. (2010). Regional flood frequency analysis of North-Bank of the River Brahmaputra by using LH-moments. Water Resources Management, 24(9), 17791790. https://doi.org/10.1007/s11269-009-9524-0

[6]. Cassalho, F., Beskow, S., de Mello, C. R., de Moura, M. M., Kerstner, L., \& Ávila, L. F. (2018). At-Site flood frequency analysis coupled with multiparameter probability distributions. Water Resources Management, 32(1), 285-300. https://doi.org/10.1007/s11269-017-1810-7

[7]. Chow, V.T. (1951). A general formula for hydrologic frequency analysis. Transactions, Americal Geophysical Union, 32(2), 231-237. https://doi.org/10.1029/TR032i002p00231

[8]. Danish, M., \& Alam, J. (2017). A softcomputing approach to flood frequency analysis of river. Hydro-2017 International, L.D. College of Engineering Ahmadabad, India, (January 2018).

[9]. Drissia, T. K., Jothiprakash, V., \& Anitha, A. B. (2019). Flood frequency analysis using L Moments: A comparison between At-Site and regional approach. Water Resources Management, 33(3), 1013-1037. https://doi.org/10.1007/s11269-018-2162-7

[10]. Ellouze, M., \& Abida, H. (2008). Regional flood frequency analysis in Tunisia: Identification of regional distributions. Water Resources Management, 22(8), 943-957. https://doi.org/10.1007/s11269-007-9203-y

[11]. Farooq, M., Shafique, M., \& Khattak, M. S. (2018). Flood frequency analysis of river Swat using Log Pearson type 3, Generalized Extreme Value, Normal, and Gumbel Max distribution methods. Arabian Journal of Geosciences, 11(9). https://doi.org/10.1007/s12517-018-3553-z

[12]. Fiorentino, M., Versace, P., \& Rossi, F. (1985). Regional flood frequency estimation using the two-component extreme value distribution.
Hydrological Sciences Journal, 30(1), 51-64. https://doi.org/10.1080/02626668509490971

[13]. Ganamala, K., \& Sundar Kumar, P. (2017). A case study on flood frequency analysis. International Journal of Civil Engineering and Technology, 8(4), 1762-1767.

[14]. Gumbel, E.J. (1941). The return period of flood flows. The Annals of Mathematical Statistics, 12(2), 163-190

[15]. Gumbel, E.J. (1958). Statistics of Extremes, Columbia University Press, New York.

[16]. Hire, P., \& Patil, A. D. (2018). Flood frequency analysis of the Par River: Western India. International Conference on Frontiers in Life and Earth Science (C) 2018 IJSRST | Volume 5 | Issue 1 | Print ISSN: 2395-6011 | Online ISSN: 2395-602X, (January).

[17].Hussain, Z., \& Pasha, G. R. (2009). Regional flood frequency analysis of the seven sites of Punjab, Pakistan, using L-moments. Water Resources Management, 23(10), 1917-1933. https://doi.org/10.1007/s11269-008-9360-7

[18]. Jeong, B. Y., Murshed, M. S., Seo, Y. A., \& Park, J. S. (2014). A three-parameter kappa distribution with hydrologic application: A generalized gumbel distribution. Stochastic Environmental Research and Risk Assessment, 28(8), 2063-2074. https://doi.org/10.1007/s00477-014-0865-8

[19]. Karim, A. M., \& Chowdhury, J. U. (1995). A comparison of four distributions used in flood frequency analysis in Bangladesh. Hydrological Sciences Journal, 40(1), 55-66. https://doi.org/10.1080/02626669509491390

[20]. Kumar, R., Chatterjee, C., Kumar, S., Lohani, A. K., \& Singh, R. D. (2003). Development of regional flood frequency relationships using Lmoments for middle Ganga plains subzone 1(f) of India. Water Resources Management, 17(4), 243257. https://doi.org/10.1023/A:1024770124523

[21]. Kumar, R., Goel, N. K., Chatterjee, C., \& Nayak, P. C. (2015). Regional flood frequency analysis 
using soft computing techniques. Water Resources Management, 29(6), 1965-1978. https://doi.org/10.1007/s11269-015-0922-1

[22]. Lee, D.-H., \& Kim, N. W. (2019). Regional flood frequency analysis for a poorly gauged basin using the simulated flood data and L-Moment method. Water, 11(8), 1717. https://doi.org/10.3390/w11081717

[23]. Lescesen, I., \& Dolinaj, D. (2019). Regional flood frequency analysis of the Pannonian Basin. Water (Switzerland), 11(2). https://doi.org/10.3390/w11020193

[24]. Loaiciga, H. A., \& Leipnik, R. B. (1999). Analysis of extreme hydrologic events with Gumbel distributions: Marginal and additive cases. Stochastic Environmental Research and Risk Assessment, 13(4), 251-259. https://doi.org/10.1007/s004770050042

[25]. McMahon, T. A., \& Srikanthan, R. (1981). Log Pearson III distribution - Is it applicable to flood frequency analysis of Australian streams? Journal of Hydrology, 52(1-2), 139-147. https://doi.org/10.1016/0022-1694(81)90100-1

[26]. Mujere, N. (2011). Flood frequency analysis using the Gumbel distribution. International Journal on Computer Science and Engineering (IJCSE), 3(7), 2774-2778.

[27]. Mukherjee, M. K. (2013). Flood frequency analysis of River Subernarekha, India, using Gumbel's Extreme Value Distribution. International Journal of Computational Engineering Research, 3(7), 12-19.

[28]. Nabi, M., Fard, P., \& Holmquist, B. (2013). Powerful goodness-of-fit tests for the extreme value distribution. Chilean Journal of Statistics, 4(1), 55-67. Retrieved from http://www.soche.cl/chjs

[29]. Nahdiya, Z. A., Mohd Bakri, A., \& Habshah, M. (2012). The Goodness-of-fit test for Gumbel distribution: A Comparative Study. Matematika, 28(1), 35-48. $\quad$ Retrieved from http://www.matematika.utm.my/index.php/mate matika/article/view/313

[30]. Noto, L. V., \& La Loggia, G. (2009). Use of Lmoments approach for regional flood frequency analysis in Sicily, Italy. Water Resources Management, 23(11), 2207-2229. https://doi.org/10.1007/s11269-008-9378-x

[31]. Onen, F., \& Bagatur, T. (2017). Prediction of flood frequency factor for Gumbel Distribution using Regression and GEP Model. Arabian Journal for Science and Engineering, 42(9), 3895-3906. https://doi.org/10.1007/s13369-0172507-1

[32]. Parida, B. P., Kachroo, R. K., \& Shrestha, D. B. (1998). Regional flood frequency analysis of Mahi-Sabarmati Basin (Subzone 3-a) using Index Flood Procedure with L-Moments. Water Resources Management, 12(1), 1-12. https://doi.org/10.1023/A:1007970800408

[33]. Raghunath, H.M. (1985). Hydrology: Principles, Analysis \& Design. National Book Trust, New Age International (P) Ltd.

[34]. Rahman, A., Haddad, K., \& Eslamian, S. (2014). Regional flood frequency analysis. Handbook of Engineering Hydrology: Modeling, Climate Change, and Variability, (February), 451-469. https://doi.org/10.1201/b16683

[35]. Saf, B. (2009). Regional flood frequency analysis using L-moments for the West Mediterranean region of Turkey. Water Resources Management, 23(3), 531-551. https://doi.org/10.1007/s11269008-9287-z

[36]. Stamatatou, N., Vasiliades, L., \& Loukas, A. (2018). Bivariate flood frequency analysis using copulas. $\quad$ Proceedings, 2(11), 635. https://doi.org/10.3390/proceedings2110635

[37]. Strupczewski, W. G., Kochanek, K., \& Bogdanowicz, E. (2014). Flood frequency analysis supported by the largest historical flood. Natural Hazards and Earth System Sciences, 
14(6), 1543-1551. https://doi.org/10.5194/nhess14-1543-2014

[38]. Subramanya, K. (2013). Engineering Hydrology. McGraw Hill Education (India) Private Limited.

[39]. Vivekanandan, N. (2015a). Comparison of Lmoments of probability distributions for extreme value analysis of rainfall for estimation of peak flood discharge for ungauged catchments. International, International Journal of Scientific Research in Science and Technology (IJSRST), 1(5), 35-41.

[40]. Vivekanandan, N. (2015b). Quantitative assessment on fitting of Gumbel and Frechet distributions for extreme value analysis of rainfall. International Journal of Scientific Research in Science and Technology (IJSRST), 2(1), 68-73.

[41]. Yadav, R., \& Lal Pande, B. B. (1998). Best fitted distribution for estimation of future flood for Rapti river systems in Eastern Uttar Pradesh. Indian Journal of Engineering and Materials Sciences, 5(1), 22-27.

[42]. Yue, S., Ouarda, T. B. M. J., Bobée, B., Legendre, P., \& Bruneau, P. (1999). The Gumbel mixed model for flood frequency analysis. Journal of Hydrology, 226(1-2), 88-100. https://doi.org/10.1016/S0022-1694(99)00168-7

[43]. Yue, Sheng. (2000). The Gumbel mixed model applied to storm frequency analysis. Water Resources Management, 14(5), 377-389. https://doi.org/10.1023/A:1011124423923

\section{Cite this article as :}

Rebati Sinam, "At Site Flood Frequency Analysis of Baitarani River at Champua Watershed, Odisha", International Journal of Scientific Research in Science and Technology (IJSRST), Online ISSN : 2395-602X, Print ISSN : 2395-6011, Volume 6 Issue 6, pp. 54-64, November-December 2019. Available at doi : https://doi.org/10.32628/IJSRST19665

Journal URL : http://ijsrst.com/IJSRST19665 